\title{
Analisis Perilaku Sosial Pengguna Moda Transportasi Perkotaan: Studi Kasus Mass Rapid Transit(MRT) DKI Jakarta
}

\author{
Andi Setyo Pambudi $^{1}$ dan Sri Hidayati ${ }^{2}$
}

\begin{abstract}
Afiliasi
${ }^{1}$ Kasubdit Pemantauan, Evaluasi dan Pengendalian Pembangunan Daerah Wilayah IV, Kementerian PPN/Bappenas Republik Indonesia

${ }^{2}$ Staf Direktorat Pemantauan, Evaluasi dan Pengendalian Pembangunan Daerah, Kementerian PPN/Bappenas Republik Indonesia
\end{abstract}

Korespondensi: andi.pambudi@bappenas.go.id

\begin{abstract}
Abstrak
Setelah melalui proses panjang, pada bulan Maret 2019, warga Jakarta memiliki Mass Rapid Transit (MRT) sebagai moda transportasi massal yang modern. Kehadiran MRT yang direncanakan sejak Tahun 1986 diharapkan menjadi salah satu solusi mengatasi kemacetan parah Jakarta yang seolah sulit ditangani. Permasalahan yang kemudian muncul adalah perilaku penumpang MRT yang tidak siap dengan segala peraturan yang harus dipenuhi dalam penggunaan MRT, sehingga ditemukan berbagai pelanggaran peraturan. Tulisan ini berusaha menyajikan analisis tentang user attitudes dan acceptability-nya sebelum dan sesudah kehadiran MRT berbasis studi literatur, big data dan analisis deskriptif kualitatif. Studi ini juga diharapkan mampu memberikan rekomendasi yang dapat diberikan dengan penekanan pada aspek sosial. Studi dilakukan menggunakan big data dan data sekunder lainnya terkait perilaku penumpang di dalam MRT dan fasilitasnya yang didapatkan dari berbagai sumber dan hasil observasi. Hasil studi menggambarkan fenomena sosial yang terjadi di masyarakat saat uji coba MRT disebabkan oleh budaya dan kesiapan masyarakat dalam menggunakan teknologi baru, serta pemberitaan MRT sejak1 (satu) tahun beroperasi mampu mengubah perilaku masyarakat yang ditunjukkan melalui hasil analisis big data.
\end{abstract}

Keywords: MRT Jakarta, Perilaku Sosial, Big Data, Analisis Sentimen

Doi: https://doi.org/10.47266/bwp.v3i2.74/ halaman: 143-156

Dikirim pada: 22 Juli 2020. Diterima pada: 31 August 2020. Dipublikasikan pada: 07 September 2020 


\section{Pendahuluan}

Salah satu upaya yang dilakukan oleh pemerintah untuk menyejahterakan masyarakat adalah dengan cara pembangunan. Pembangunan juga harus berkelanjutan yang didapatkan dari pemahaman manusia terkait penyelesaian masalah dunia (Sachs, 2015; Koengkan et al., 2020). Konsep pembangunan berkelanjutan berawal dari kesadaran manusia terhadap keberlanjutan lingkungan (Larasati, 2016). Pembangunan berkelanjutan mencakup tiga pilar penting dalam pelaksanaannya, yaitu ekonomi, sosial, dan lingkungan (Sutopo et al., 2014). Pembangunan ekonomi adalah salah satu bagian penting pembangunan yang menuju keberlanjutan efisiensi ekonomi, kesejahteraan, dan pemerataan (Erwandari, 2017). Pengukuran capaian kualitas pembangunan dengan hanya berpatokan pada pertumbuhan ekonomi sudah pasti tidak cukup untuk menggambarkan kondisi kesejahteraan seutuhnya (Sachs, 2015; Damayanti \& Chamid, 2016). Paradigma keberhasilan pembangunan juga berpatokan pada indikator-indikator komposit yang bukan hanya mengukur dari sisi material saja tetapi juga kemajuan-kemajuan yang terkait dengan sisi pembangunan manusia.

Jakarta adalah ibukota negara Indonesia yang memiliki segala daya tarik dan magnet bagi penduduk dari berbagai latar suku bangsa dan negara untuk beraktivitas didalamnya (Yudhistira et al., 2018). Padatnya penduduk Jakarta disebabkan kedudukan Jakarta sebagai pusat bisnis, politik, dan kebudayaan sehingga masyarakat dari berbagai wilayah di Indonesia berdatangan ke Jakarta untuk mencari pekerjaan (Jones et al., 2016). Jakarta juga dikelilingi beberapa wilayah penyangga disekitarnya yang terdiri dari Bogor, Depok, Tangerang, dan Bekasi. Kota-kota tersebut sebagian masyarakatnya bekerja di Jakarta sehingga menambah padatnya arus transportasi dan kemacetan di Jakarta. Berdasarkan data resmi Indonesia, jumlah penduduk Jakarta pada Tahun 2015 adalah 10,18 juta orang (BPS Team, 2016), meningkat menjadi 10,28 juta orang pada Tahun 2016 (BPS Team, 2017). Pada Tahun 2017, Kota Jakarta memiliki penduduk 10,37 juta orang yang berarti bahwa selama dua tahun terakhir jumlah penduduk kota ini bertambah 269 orang per hari atau 11 orang per jam (BPS Team, 2018).

Banyaknya jumlah penduduk ini berbanding lurus dengan banyaknya mobilitas sehari-hari dan meningkatnya kemacetan. Penyebab kemacetan di perkotaan salah satunya adalah meningkatnya kecenderungan pemakai jasa transportasi untuk menggunakan kendaraan pribadi dibandingkan dengan kendaraan umum (Tamin, 2000). Perbaikan kondisi ekonomi dan mudahnya memiliki kendaraan pribadi mendorong peningkatan tingkat kepemilikan kendaraan tanpa diimbangi upaya peningkatan pelayanan transportasi umum itu sendiri. Kurangnya minat masyarakat menggunakan transportasi umum adalah menyangkut lamanya waktu tempuh lama, sarana dan prasarana yang kurang memadai, jumlah penumpang yang melebihi kapasitas angkut, tingkat kenyamanan yang rendah, serta sistem jaringan yang kurang memadai (Wells, 1975; Tamin, 2000). Masyarakat menginginkan sarana transportasi yang ramah, aman, efektif dan efisien yang sesuai dengan tuntutan mobilitas mereka. Oleh sebab itu, salah satu langkah untuk mengubah gaya transportasi dari penggunaan kendaraan pribadi menjadi pengguna transportasi umum adalah dengan adanya sistem dan proyek pembangunan Mass Rapid Transit.

Mass Rapid Transit (MRT) dipandang sebagai salah satu solusi untuk menjawab masalah mobilitas penduduk dan masalah kemacetan di Jakarta. Pembangunan MRT ini akan berkembang sebagai moda transportasi baru dengan peningkatan kenyamanan dan 
layanan menggunakan fasilitas bawah tanah yang lebih modern. Fasilitas sistem transportasi MRT ini sangat diperlukan di Kota Jakarta sebagai akses ke pusat kota dan area Central Business District (CBD), menghubungkan dengan moda transportasi Trans Jakarta yang jaringannya semakin meluas saat beroperasi, serta untuk membantu keadaan transportasi saat ini di metropolitan Jakarta. Keunggulan transportasi ini daripada opsi lain untuk mengatasi kemacetan adalah dapat mengangkut penumpang dalam jumlah banyak dengan waktu yang cepat, tidak menggunakan jaringan jalan raya, hemat bahan bakar minyak (BBM) dan dapat mengurangi tingkat polusi udara sehingga mendukung peningkatan kualitas lingkungan. Pada bulan Maret 2019, Provinsi DKI Jakarta telah mulai menggunakan Mass Rapid Transit untuk pertama kalinya. Tahap awal pembangunan MRT Jakarta ini bertujuan untuk layanan publik antara Pusat Kota (Monas) dan Terminal Bus Suburban (Lebak Bulus) yang panjangnya sekitar $15 \mathrm{~km}$ dan termasuk segmen elevated dan underground.

Permasalahan yang timbul setelah adanya moda transportasi ini adalah kesiapan warga Jakarta dan sekitarnya dalam memanfaatkannya secara berkelanjutan. Sebagai contoh adalah viralnya foto-foto di pemberitaan nasional tentang pengguna MRT yang bergelantungan, makan didalam area MRT dan membuang sampah sembarangan serta berdiri di kursi MRT itu sendiri. Perilaku penumpang yang tidak tertib di masa-masa awal pengoperasian moda raya terpadu (MRT) ternyata bukan hanya terjadi di Jakarta, melainkan juga di Singapura. Penduduk Singapura saat itu juga tidak disiplin saat awal MRT beroperasi pada 1987 (Zhu \& Liu, 2004). Hal yang menjadi perhatian adalah pada tahun 2019 ini ternyata perilaku sosial pengguna MRT di Jakarta tidak jauh berbeda seperti di Singapura tahun 1987.
Saat ini ada hampir 1 miliar kendaraan bermotor di dunia, jumlahnya terus bertambah dengan cepat. Di Jepang sebagai produsen mobil, penduduknya lebih memilih menggunakan moda transportasi Mass Rapid Transit (MRT) yang pengunaannya lebih murah, mudah, dan cepat. Jepang memiliki salah satu sistem kereta api terbaik di dunia. Dibandingkan New York dan London, Jepang memiliki posisi tertinggi dalam penggunaan transportasi umum. Sekalipun Tokyo juga sebagai kota dengan kepemilikian kendaraan mobil tertinggi (Rogers et al., 2012). Hal ini menunjukkan ekspektasi masyarakat pada MRT di Jepang terpenuhi dengan baik sehingga MRT mampu menarik banyak penumpang dan menjadi salah satu transportasi publik yang berhasil dalam mengatasi permasalahan kebutuhan mobilitas penduduknya. Keberhasilan Jepang tersebut seharusnya dapat menjadi stimulan dan pendorong bagi kota-kota di Asia seperti Hanoi, Bangkok dan Jakarta dengan penggunaan kendaraan roda dua (motor) yang lebih tinggi untuk mobilisasi agar mulai investasi ke pembangunan sistem MRT. Hal tersebut bertujuan agar dapat memenuhi peningkatan permintaan perjalanan penduduk dan untuk mengurangi penggunaan motor yang mendominasi perjalanan (Tuan, 2015).

Pengenalan sistem MRT di daerah perkotaan dapat dipandang sebagai pengenalan teknologi transportasi baru dari perspektif pengguna angkutan umum yang harus diperhatikan dalam konteks penerimaan teknologi agar dapat memprediksi keberhasilan penggunaan MRT (Chen \& Chao, 2011). Pemahaman tentang sikap dan perilaku pengguna sebagai penumpang adalah hal yang diperlukan untuk pengembangan dari sistem transportasi yang efektif agar mendorong penggunaan yang lebih efisien dari sistem transportasi umum perkotaan (Fatima \& 
Kumar, 2014). Pilihan transportasi yang digunakan seseorang dipengaruhi oleh beberapa faktor, seperti karakteristik individu dan gaya hidup, jenis perjalanan, dan kinerja layanan yang dirasakan dari masing-masing moda transportasi (Beirão \& Cabral, 2007). Sangat penting memahami perilaku penumpang angkutan umum bagi pembuat kebijakan untuk menciptakan kebijakan yang ramah agar dapat menekan pertumbuhan kendaraan pribadi, karena tanpa memahami perilaku penumpang angkutan umum, kebijakan pemerintah akan berakhir menjadi sia-sia (Sumaedi et al., 2014). Dalam rangka mengetahui kebijakan transportasi publik berhasil diterapkan, perlu dilakukan survei terhadap user attitudes dan acceptability-nya sebelum dan sesudah kebijakan diterapkan (Bhattacharjee et al., 1997). Tulisan ini berusaha menyajikan analisis tentang user attitudes dan acceptability-nya sebelum dan sesudah kehadiran MRT berbasis studi literatur, big data dan analisis deskriptif kualitatif.

\section{Metodologi}

Metode yang digunakan dalam studi ini adalah studi literatur, analisis big data dan analisis deskriptif kualitatif. Studi literatur digunakan untuk mengetahui hasil-hasil penelitian sebelumnya yang berkaitan dengan tujuan pada penelitian ini. Selain itu, studi literatur juga dilakukan untuk mendapatkan data-data sekunder yang diperlukan pada penelitian ini diantaranya yaitu big data pemberitaan tentang pengoperasian awal MRT di Jakarta dan setelahnya. Setelah data-data tersebut didapatkan, kemudian dilakukan pengolahan/analisis data dan penyajian data.

Langkah selanjutnya adalah analisis deskriptif kualitatif. Metode ini dipilih karena data-data yang ada merupakan fenomena yang terjadi saat awal pengoperasian MRT Jakarta yang bersifat alamiah dan memperhatikan kualitas dan kaitan antara satu kejadian dengan kejadian lainnya (Sukmadinata, 2011). Selain itu, metode ini digunakan juga karena dalam penelitian ini tidak perlakuan ataupun manipulasi yang diberikan pada variabelvariabel yang diteliti, tetapi hanya berusaha menggambarkan suatu kondisi telah terjadi tanpa suatu rekayasa. Selain itu, metode ini digunakan untuk mengetahui faktor-faktor yang menyebabkan terjadinya pelanggaran peraturan penggunaan MRT yang dilakukan penumpang pada masa uji coba.

Analisis lain yang dilakukan dalam penelitian ini adalah sentiment analysis dengan memanfaatkan big data, yaitu merupakan proses klasifikasi dokumen tekstual ke dalam beberapa kelas seperti sentimen positif dan negatif serta besarnya pengaruh dan manfaat dari sentiment analysis tersebut (Nomleni et al., 2013). Software yang digunakan untuk mengolah big data adalah R Studio. Pada penelitian ini dibahas sentimen pemberitaan terkait MRT Jakarta berbasis artikel online dan google trend. Hal ini bertujuan untuk mengetahui sejauh mana atensi masyarakat di Indonesia terhadap perilaku pengguna MRT Jakarta yang dimiliki Indonesia periode Januari - Mei 2019 serta halhal yang dapat menjadi masukan bagi pengambil kebijakan terkait MRT ke depan. Analisis dengan memanfaatkan big data juga membahas pemberitaan pengguna MRT diberbagai negara dibandingkan Indonesia dan dampaknya terhadap perubahan perilaku. Analisis fenomena sosial berbasis big data juga melihat pada periode saat terjadi pada rentang data analisis Januari - Mei 2020. Pada awal tahun 2020, pemberitaan banyak mengulas bagaimana perilaku masyarakat setelah 1 (satu) tahun MRT beroperasi.

\section{Hasil dan Pembahasan}

\subsection{Penerapan Mass Rapid Transport (MRT) di Jakarta}


Tahap awal pengoperasian MRT Jakarta yang dimulai sejak Maret 2019, disambut dengan antusiasme 332.284 masyarakat (seminggu pertama operasi) terhadap adanya moda transportasi baru yang diharapkan akan menjadi salah satu solusi transportasi umum yang nyaman, aman, cepat, dan tentunya lebih modern. Diperlukan adanya survei terhadap perilaku pengguna dan penerimaan dari masyarakat, adanya pembangunan MRT di awal ini selain sebagai sarana transportasi juga sebagai tempat berkunjung masyarakat yang menunjukkan euphoria terhadap sesuatu yang baru dan modern. Salah satu strategi untuk mengetahui sejauh mana penerimaan masyarakat terhadap MRT ini telah dilakukan pengelola MRT dengan membuka masa operasi tak berbayar dalam periode tertentu dan terbukti melebihi jumlah target 65.000 penumpang per hari. Rata-rata penumpang per hari adalah 89.645 orang (PT. MRT Jakarta, 2020).

Data dari PT. MRT Jakarta (2020), diketahui bahwa Tahun 2019 merupakan tahun pertama layanan operasional MRT Jakarta. Pada tanggal 24 Maret 2019, MRT Jakarta resmi beroperasi untuk masyarakat umum. Terdapat beberapa strategi dalam pengenalan MRT Jakarta. Selama satu minggu awal beroperasi, MRT Jakarta memberikan promosi gratis terhadap seluruh pengguna jasa. Setelah itu, mulai dari 1 April 2019 hingga 12 Mei 2019 MRT Jakarta memberikan promosi diskon 50\% dari tarif normal kepada seluruh pengguna jasa. Selama periode 2019, MRT Jakarta mengalami fluktuasi kenaikan dan penurunan pengguna jasa setiap bulannya. Di sepanjang tahun 2019 pengguna jasa MRT tercatat mencapai 24.621.467 pengguna jasa dengan rata-rata 89.645 pengguna jasa per hari.

Pilihan transportasi yang dipengaruhi faktor karakteristik individu dan gaya hidup, nyatanya dapat berlaku sebaliknya (Beirão \& Cabral, 2007). Menurut Stoner \& Freeman (1989), karakteristik individu adalah minat, sikap dan kebutuhan seseorang terhadap sesuatu. Sementara itu, gaya hidup didefinisikan sebagai pola hidup seseorang di dunia yang diekspresikan pada sebuah aktivitas, minat, serta opini dari orang tersebut (Kotler \& Keller, 2008)

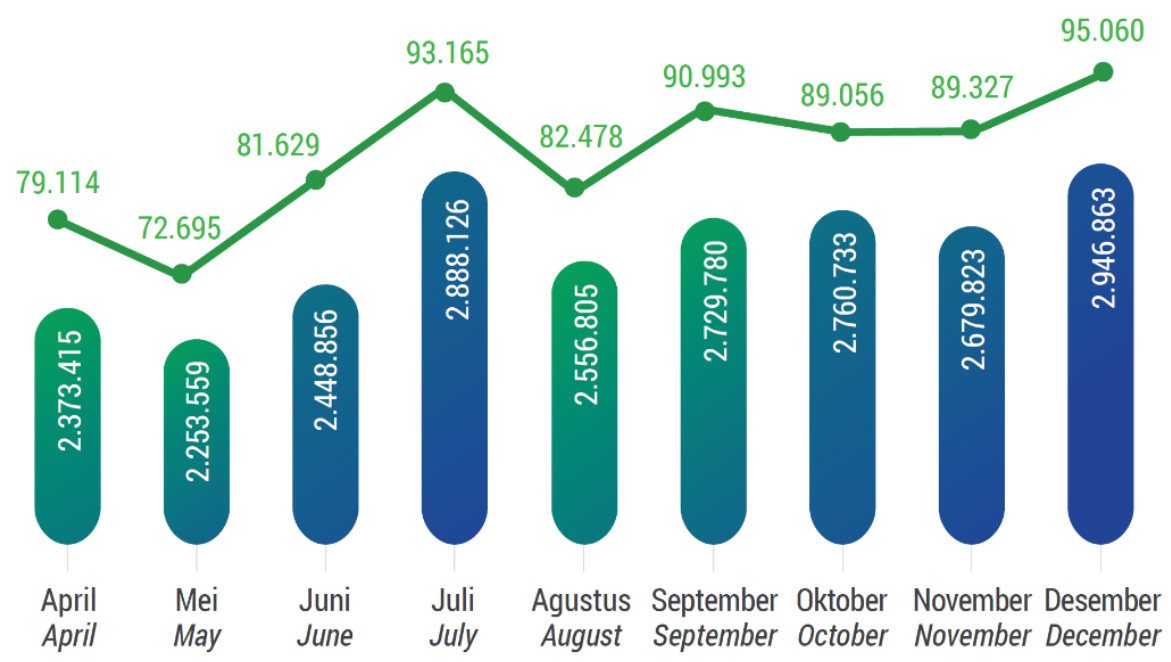

Gambar 1. Jumlah Penumpang MRT Jakarta dan Rata-Rata Pengguna Jasa MRT Per Hari di Setiap Bulan Tahun 2019

Sumber: PT. MRT Jakarta, 2020 (diolah) 
Pada tahun 2019, penumpang MRT Jakarta didominasi oleh pegawai kantor yang memang pada umumnya bekerja di daerah Sudirman- Thamrin sesuai dengan rute MRT yang tersedia saat ini. Hal ini dapat menunjukkan bahwa dengan adanya MRT dapat mempengaruhi gaya hidup. Misalnya, seorang pegawai kantor yang awalnya menggunakan kendaraan pribadi atau kendaraan umum berbasis online mengubah pola mobilisasinya menggunakan MRT. Hal ini dapat terjadi karena keberadaan MRT dapat mempermudah aktivitas dan mobilisasi mereka untuk menuju tempat bekerja sehari-hari dengan mempersingkat waktu tempuh dan mengefisienkan biaya dibandingkan dengan menggunakan kendaraan pribadi atau transportasi umum lainnya. Selain karena kebutuhan menuju dan kembali dari tempat kerja, MRT ini menjadi fasilitas mobilisasi pegawai kantor pada jam istirahat, seperti ramainya Stasiun Blok $M$ dan Bundaran HI pada jam istirahat tersebut. Maka dari itu, pilihan transportasi tidak hanya dipengaruhi, tetapi juga mempengaruhi karakteristik dan gaya hidup individu.

Sebuah kebijakan hendaknya dapat memahami perilaku penumpang angkutan umum, dimana juga melihat dari perspektif dari penyedia fasilitas MRT agar kebijakan dapat dipahami dan diberlakukan bersama. Dalam hal ini, penumpang sebagai pengguna fasilitas MRT perlu diinformasikan dan mengimplementasikan kebijakan yang berlaku agar sesama penumpang dapat menggunakan fasilitas MRT dengan nyaman dan aman. Dari segi penyedia fasilitas pun perlu memahami saran dari penumpang terhadap perbaikan atau penyediaan fasilitas yang tepat-guna agar perilaku penumpang dapat memenuhi kebijakan yang berlaku. Misalnya, adanya kebijakan tidak diperkenankan makan dan minum di dalam MRT. Penyedia fasilitas sudah berupaya dengan tidak menyediakan tempat sampah dalam MRT sebagai pola pembiasaan bagi penumpang untuk menjaga kenyamanan dan kebersihan di dalam MRT. Hal ini didukung pula dengan tidak adanya para pedagang di sekitar stasiun dengan tujuan agar pembiasaan bagi perilaku pengunjung untuk menjaga kenyamanan dan membudayakan stasiun MRT yang modern.

\subsection{Analisis Deskriptif Kualitatif}

Kehadiran MRT yang dianggap sebagai fasilitas dan teknologi baru yang belum pernah ada sebelumnya di Indonesia, menjadikan MRT sebagai tujuan "wisata” baru untuk masyarakat pada masa uji coba. Meskipun demikian, hal yang disayangkan adalah sikap beberapa pengguna MRT yang melanggar peraturan pada masa uji coba tersebut seperti dudukduduk di dalam stasiun, serta membawa makanan dan minuman dari rumah untuk dimakan di stasiun (Fajri, 2019). Fenomena tersebut terjadi karena perubahan teknologi yang ditawarkan MRT menuntut masyarakat untuk menerima hal-hal baru yang berkaitan dengan tata tertib penggunaan fasilitas MRT. Hal yang terjadi pada masa uji coba adalah sebagian orang belum dapat menerima perubahan tersebut. Penentu utama akseptabilitas terhadap suatu teknologi baru adalah pengetahuan dan kesadaran, latar belakang sosiodemografi dan pengetahuan lingkungan (Thesen \& Langhelle, 2008). Perilaku masyarakat yang melanggar peraturan penggunaan MRT, dapat terjadi karena faktor kurangnya pengetahuan dan kesadaran dini masyarakat tentang peraturan penggunaan fasilitas umum tersebut. Padahal, pihak MRT telah mengeluarkan peraturan mengenai larangan dan aturan ketika menggunakan MRT seperti yang dapat dilihat pada Gambar 2. 


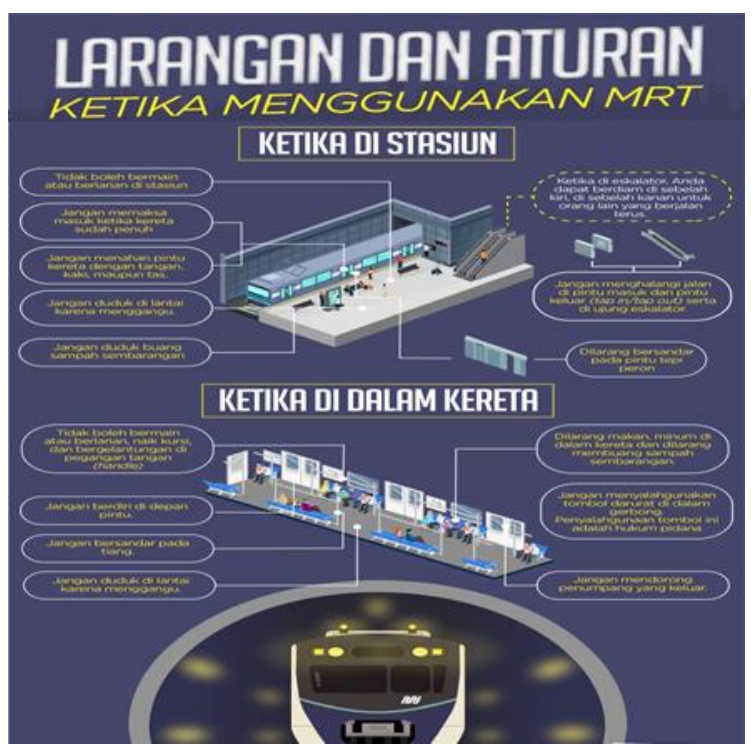

Gambar 2. Peraturan Penggunaan MRT Jakarta

Sumber: PT. MRT Jakarta, 2020 (diolah)

Dalam hal law enforcement, pihak MRT telah berupaya menegakkan peraturan tersebut. Upaya-upaya tersebut dilakukan salah satunya oleh petugas MRT dalam menjalankan tugas dan fungsinya telah berupaya untuk menerapkan komunikasi dan sosialisasi sebagai bentuk proses dalam lingkungan sosialnya. Petugas telah mencoba untuk memberikan peringatan kepada penumpang yang melanggar peraturan tersebut, namun karena keterbatasan kontrol petugas yang berjumlah kurang lebih 1000 orang pada masa uji coba yang tidak seimbang dengan jumlah penumpang uji coba pada masanya sebanyak sekitar 90.000 penumpang, upaya petugas tidak terlalu signifikan terhadap perubahan perilaku penumpang dalam menaati peraturan.

Selain itu, masyarakat masih belum terbiasa dengan perbedaan fasilitas yang ada pada MRT dibandingkan dengan moda transportasi lainnya. Kebiasaan tidak mematuhi peraturan yang dianggap "ringan” juga menjadikan pelanggaran-pelanggaran terjadi saat masa uji coba MRT. Sebagai contoh, moda transportasi angkutan umum yang ada di Indonesia sebagian besar tidak tertib dalam hal menurunkan dan menaikkan penumpang, sehingga hal tersebut membentuk kebiasaan masyarakat untuk tidak antri di halte-halte yang telah disediakan (Joewono \& Kubota, 2006). Kebiasaan duduk-duduk di tempat yang bukan fasilitasnya yang sudah sering terjadi sebelumnya di fasilitas umum.

Perilaku tersebut juga disebabkan adanya perbedaan kultur dan gaya hidup masyarakat saat ini. Gaya hidup yang tidak disiplin, kultur budaya yang cenderung menerima dan memaklumi pelanggaran peraturan, serta kesadaran hukum di Indonesia yang masih rendah membuat pelanggaran-pelanggaran semacamnya masih sering ditemukan (Hasibuan, 2016).

Efektivitas hukum dalam masyarakat ditentukan oleh berbagai faktor yaitu faktor hukumnya sendiri, faktor penegak hukum, faktor fasilitas, faktor kesadaran hukum masyarakat, dan faktor budaya hukum (Soekanto, 1977). Efektivitas hukum dapat diartikan sebagai kemampuan hukum menciptakan situasi seperti yang dikehendaki oleh hukum. Dalam kenyataannya. hukum itu tidak hanya berfungsi sebagai sosial kontrol, tetapi dapat juga menjalankan fungsi perekayasaan sosial (Yudo \& Tjandrasar, 2017)

\subsection{Analisis Sentimen Berbasis Big Data}

Pengambilan keputusan yang baik pada dasarnya didukung oleh data. Keuntungan yang optimal dari sebuah data akan didapat oleh para pihak yang peka dengan perkembangan zaman untuk mampu mengolah data yang beragam, memiliki kompleksitas tinggi serta volume yang besar atau yang biasa disebut dengan big data (Sirait, 2016). Oleh karena itu, dalam beberapa tahun terakhir, big data dengan cepat mengubah wajah ekonomi global sejalan dengan kecepatan pertumbuhan layanan analitik data berbasis jaringan (Tao, et al., 2019). Sejak meluasnya penggunaan teknologi big data di Indonesia di 
sekitar tahun 2013, banyak sektor privat yang telah memanfaatkan teknologi tersebut untuk mengembangkan bisnisnya meskipun penerapannya di sektor publik/pemerintahan tampaknya masih terbatas (Aryasa 2015; Sirait 2016).

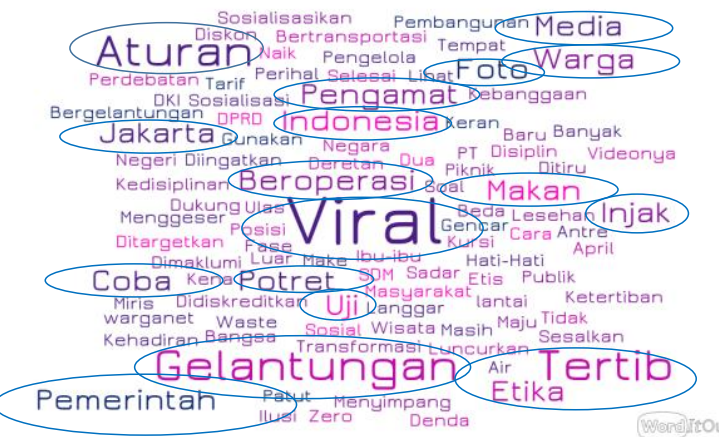

Gambar 3. WordCloud Pemberitaan di Google News Terkait Perilaku Pengguna MRT Jakarta Sumber: Diolah dari Berbagai Judul Artikel di Google Neres dengan Sofware Rstudio

Analisis berbasis big data dapat dilakukan untuk menilai sentimen masyarakat terhadap perilaku sosial, khususnya dalam menggunakan transportasi umum, termasuk MRT. Masyarakat DKI Jakarta menyambut beroperasinya MRT dengan uji coba gratis di bulan 24 Maret 2019 yang diikuti 4000 orang. Antusiasme warga Jakarta pada hari pertama pembukaan komersil juga tetap sama besarnya yang ditandai dengan antrian tiket cukup panjang. Calon penumpang tersebut berdiri antri di loket tiket, baik di loket pembelian manual maupun di vending machine(tiket mesin). Perilaku pengguna MRT di Indonesia sejak uji coba gratis sampai pengoperasian secara komersial menjadi hal yang yang menarik perhatian, baik di media massa maupun media online. Ujicoba awal MRT terlihat bahwa masyarakat tidak tertib seperti bergelantungan, menginjak kursi, makan lesehan, membuang sampah sembarangan, dan tidak tertib antri masuk, telah banyak membuat warganet geram terlihat dari komentar-komentar di media cetak dan media online. Selain media sosial, berdasarkan hasil penelusuran artikel online terkait perilaku pengguna MRT Jakarta juga menunjukkan kumpulan kata-kata yang menggambarkan hal tidak jauh berbeda dengan apa yang tersebar luas di media sosial.

Berdasarkan hasil wordcloud tentang perilaku pengguna MRT di Indonesia yang dirangkum dari artikel-artikel online, dapat diketahui apa yang sering menjadi perbincangan dan pemberitaan warganet terkait dengan MRT Jakarta. Berdasarkan wordcloud tersebut, pengguna MRT sering dihubungkan dengan "viral”, "gelantungan", "makan”, “injak", "etika”, dan kata-kata komentar negatif lainnya. Selain itu, warganet juga sering mengaitkan pengguna MRT dengan kata "pemerintah”, “Jakarta”, "pengamat”, “aturan”, "tertib”. Kondisi riil dilapangan sesuai dengan yang ada di pemberitaan sehingga worlcloud tersebut sesuai dengan denga fakta yang ada. Hal ini menunjukkan bahwa selain mengkritik perilaku pengguna MRT yang tidak tertib, warganet juga berharap pemerintah untuk terus mensosialisasikan aturan-aturan agar masyarakat pengguna MRT dapat tertib.

Hasil penelusuran selanjutnya, setelah viral tindakan tidak terpuji pengguna MRT, pemberitaan masyarakat mengenai pengguna layanan MRT mulai menunjukkan bahwa masyarakat pengguna MRT telah berubah mengarah lebih baik dan tertib. Menelusuri berita-berita di media online pada situs google trend, frekuensi banyaknya berita yang membahas mengenai MRT Jakarta mulai intens bermunculan pada Bulan Februari 2019 hingga setelahnya, seperti yang terlihat pada grafik di Gambar 4, dengan puncak frekuensi terbanyak terjadi pada 24-30 Maret 2019. 


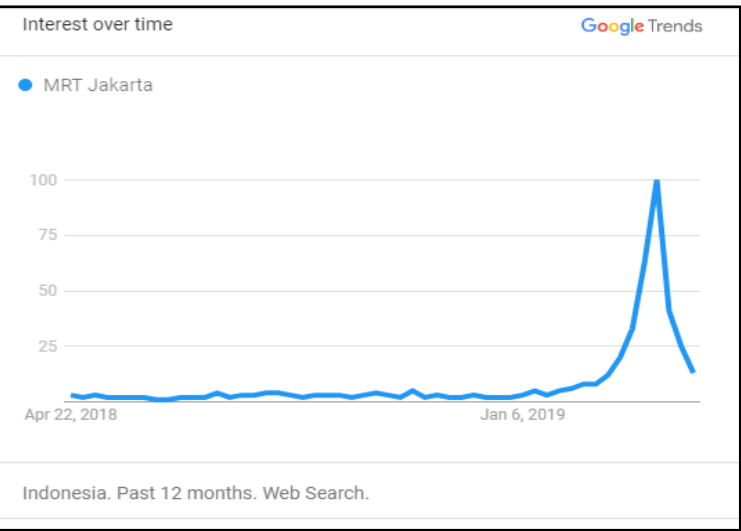

Gambar 4. Pemberitaan di Indonesia Terkait MRT Jakarta

Sumber: Google Trend, 2019

Kondisi perbaikan perilaku penumpang akibat dari viralnya perilaku-perilaku melanggar peraturan menandakan bahwa pengguna MRT mengetahui adanya beritaberita negatif tersebut. Hal ini sejalan dengan konsep perubahan sosial menurut Gillin \& Gillin (1948) yaitu terjadi disebabkan adanya perubahan di lingkungan, kebudayaan, penduduk, ideologi ataupun temuan-temuan baru di masyarakat. Ketika seseorang membuat penilaian dan keputusan tentang masalah yang mereka tidak sadari, mereka bergantung pada kepercayaan untuk menebus kurangnya informasi (Siegrist \& Cvetkovich, 2000). Dalam hal perubahan perilaku masyarakat sebagai pengguna MRT yang semula melanggar banyak peraturan penggunaan MRT pada masa awal uji coba dipengaruhi oleh kekuatan media masa/media sosial dalam hal pengangkatan isu pelanggaran tata tertib penggunaan MRT, sehingga hal tersebut menjadi viral dan sampai pada individu-individu masyarakat yang sempat menjadi pelanggar tata tertib tersebut. Sikap publik berubah karena pengalaman pribadi yang memberi pemahaman baru tentang implikasi dari tuduhan untuk kesejahteraan pribadinya sendiri (Winslott et al., 2009).
Tabel 1. Jumlah Sentimen Pemberitaan

Terkait Perilaku Pengguna Moda Transportasi Umum “MRT Jakarta” Pada Fase Awal Operasi

\begin{tabular}{ccc}
\hline Bulan & Sentimen Pemberitaan & Jumlah \\
\hline \multirow{3}{*}{ Januari } & Neutral & 13 \\
\cline { 2 - 3 } & Negative & 3 \\
\cline { 2 - 3 } Februari & Positive & 6 \\
\cline { 2 - 3 } & Neutral & 25 \\
\cline { 2 - 3 } & Negative & 5 \\
\hline \multirow{3}{*}{ Maret } & Positive & 22 \\
\cline { 2 - 3 } & Neutral & 95 \\
\cline { 2 - 3 } April & Negative & 8 \\
\cline { 2 - 3 } & Positive & 47 \\
\cline { 2 - 3 } & Neutral & 18 \\
\hline \multirow{3}{*}{ Mei } & Negative & 9 \\
\cline { 2 - 3 } & Positive & 9 \\
\cline { 2 - 3 } & Neutral & 9 \\
\cline { 2 - 3 } & Negative & Positive
\end{tabular}

Sumber: Hasil Analisis Big Data, 2019

Kecenderungan naiknya sentimen negatif pada Tabel 1 menunjukkan bahwa semakin banyak penambahan penumpang MRT tiap bulan, berbanding lurus dengan pemberitaan negatif tentang perilaku pengguna MRT di fase awal operasinya. Selain itu, pemberitaan tentang MRT Jakarta saat itu juga telah menjadi perhatian dunia. Beberapa negara yang juga mengulas pemberitaan mengenai MRT Jakarta adalah Jepang, Belanda, Korea Selatan, dan Taiwan. Pemberitaan dan perbandingannya dengan perilaku penumpang di Singapura yang lebih tertib memicu aksi warganet Indonesia untuk mengingatkan agar menjadi lebih baik karena ada sanksi sosial dalam masifnya berita negatif, baik berita online maupun offline.

Setelah adanya pemberitaan viral dan masif tentang perilaku pengguna MRT Jakarta pada awal operasinya yang dinilai negatif, 
ternyata efek berita ini cukup dapat merubah perilaku masyarakat pengguna MRT selanjutnya. Faktor pendorong utama perubahan ini adalah sanksi sosial yang masif ketika foto perilaku yang negatif di fasilitas
MRT tersebar jelas dan luas di berbagai linimasa berita serta dapat disaksikan keluarga, teman, tetangga dan masyarakat secara global dengan mudah.

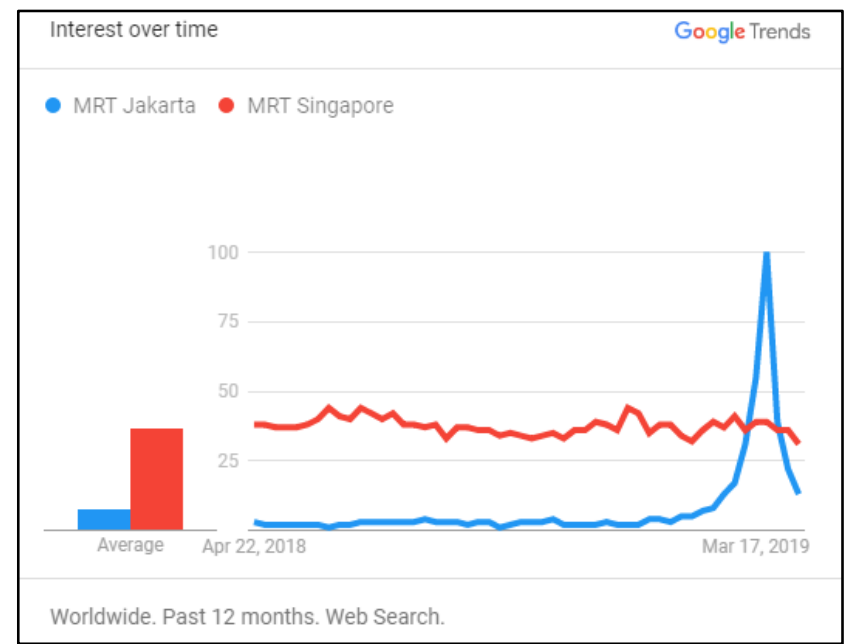

Gambar 5. Pemberitaan di Dunia Terkait MRT Jakarta dan MRT Singapura

Sumber: Diolah dari Google Trend, 2019

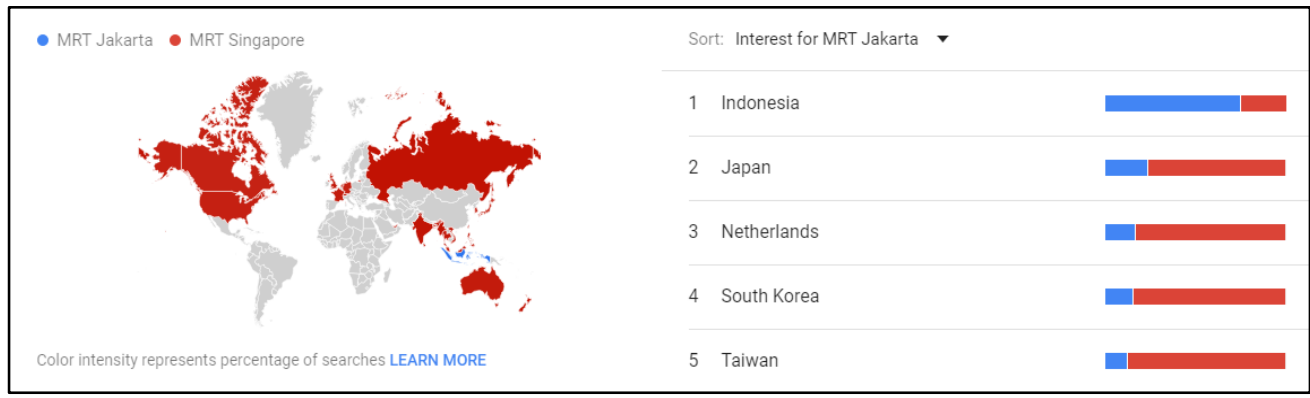

Gambar 6. Pemberitaan di Dunia Terkait MRT Jakarta (Indonesia)

Sumber: Diolah dari Google Trend, 2019 


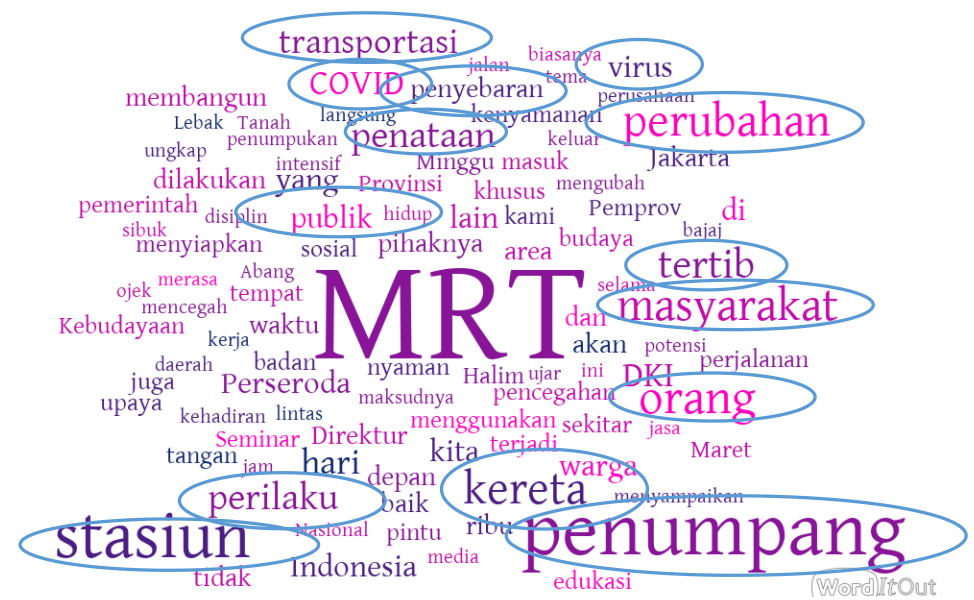

Gambar 7. WordCloud Pemberitaan Terkait MRT Jakarta di Tahun 2020

Sumber: Diolah dari Berbagai Judul Artikel di Google News dengan Sofware Rstudio

Pada tahun 2020, dalam periode bulan yang sama yaitu Januari - Mei 2020 atau 1 (satu) tahun sejak MRT beroperasi, hasil pemberitaan memperlihatkan bahwa MRT telah mampu mengubah perilaku masyarakat (PT. MRT Jakarta, 2020). Setelah viralnya pemberitaan negatif pengguna MRT Jakarta, masyarakat telah tertib dan disiplin dalam mematuhi aturan di MRT, seperti tidak membuang sampah sembarangan di area stasiun, tertib saat di dalam MRT maupun saat keluar masuk MRT, serta tertib saat keluar stasiun melalui pintu yang sudah ditentukan.

\section{Kesimpulan dan Saran}

Fenomena sosial yang terjadi saat masa uji coba MRT Jakarta yang ditemukan dari berbagai sumber adalah terkait kesiapan masyarakat dengan moda transportasi baru yang modern. Analisis berbasis big data dapat dilakukan untuk menilai sentimen masyarakat terhadap perilaku sosial, khususnya dalam mengakses transportasi umum, termasuk MRT ada hal-hal yang diperbolehkan maupun dilarang untuk dilakukan.

Perilaku pengguna MRT pada masa awal uji coba yang semula negatif menjadi positif dipengaruhi oleh kekuatan media ketika mengangkat isu ini secara masif, sehingga hal tersebut menjadi viral. Hasil analisis big data menunjukkan bahwa ada perubahan perilaku pengguna MRT Jakarta ke arah positif setelah sebelumnya sentimen negatif dalam pemberitaan yang viral. Fenomena ini menunjukkan bahwa untuk mengubah perilaku masyarakat untuk sadar akan tertib aturan memang membutuhkan waktu yang tidak instan. Hal yang patut diapresiasi adalah ternyata peran media sangat signifikan dalam perubahan yang terjadi di masyarakat. Pemerintah dan penyedia layanan MRT disarankan melibatkan peran media yang lebih optimal sebagai social control karena terbukti efektif dan efisien terhadap perilaku masyarakat.

\section{Daftar Pustaka}

Alvin L. Betrand. (1980). Sosiologi, terjemahan: Sanapiah S. F, Jakarta: Penerbit CV. Rajawali.

Aryasa, K. (2015). Big Data: Challenges and Opportunities. Disampaikan dalam Workshop Big data Puslitbang Aptika dan IKP pda tanggal 19 Mei 2015. Puslitbang Aptika dan IKP. 
Bhattacharjee, D., Haider, S.W., Tanaboriboon, Y., \& Sinha, K.C. (1997). Commuters Attitudes Towards Travel Demand Management in Bangkok. Journal of Transport Policy. DOI: 10.1016/So967070X(97)00004-8

Beirão, G., \& Cabral, J.A.S. (2007). Understanding attitudes towards public transport and private car: A qualitative study. Journal of Transport Policy. https://doi.org/10.1016/j.tranpol.2007. 04.009

BPS Team. (2018). DKI Jakarta Dalam Angka Tahun 2017. Jakarta: Badan Pusat Statistik.

BPS Team. (2017). DKI Jakarta Dalam Angka Tahun 2016. Jakarta: Badan Pusat Statistik.

BPS Team. (2016). DKI Jakarta Dalam Angka Tahun 2015. Jakarta: Badan Pusat Statistik.

Chen, C.F. \& Chao, W.H. (2011). Habitual or reasoned? Using the theory of planned behavior, technology acceptance model, and habit to examine switching intentions toward public transit. Journal of Transportation Research Part F: Traffic Psychology and Behaviour.https://doi.org/10.1016/j.trf. 2010.11.006

Damayanti, R. \& Chamid, M.S. (2016). Analisis Pola Hubungan PDRB dengan Faktor Pencemaran Lingkungan di Indonesia menggunakan

Pendekatan Geographically Weighted Regression (GWR). Jurnal Seni dan Sains ITS Volume 5 No. 1. DOI: 10.12962/j23373520.v5i1.14170

Erwandari, Nelti. (2017). Implementasi Sustanaible Development Goals (SDGs) dalam Meningkatkan Ketahanan Pangan di Provinsi Riau. eJournal Hubungan
Internasional. 5(3): 875-888. Submitted on Aug 9, 2017.

Fatima, E., \& Kumar, R. (2014). Introduction of public bus transit in Indian cities. International Journal of Sustainable Built Environment, 3(1), 27-34. DOI: https://doi.org/10.1016/j.ijsbe.2014.06. OO 1

Gillin, J. L., \& Gillin, J. P. (1948). Cultural sociology. McMillan, New York.

Hasibuan, Zulkarnain. (2013). Kesadaran Hukum dan Ketaatan Hukum Masyarakat Dewasa Ini. JUSTITIA: Jurnal Ilmu Hukum dan Humaniora, Vol 1, No 01 (2013)

Joewono, T. B., \& Kubota, H. (2006). Safety and Security Improvement in Public Transportation Based On Public Perception in Developing Countries. IATSS Research, 30(1), 8610O. doi:10.1016/s0386-1112(14)60159$\mathrm{x}$

Jones, G.W., Rangkuti, Hasnani, Utomo, A.J, \& McDonald, P. (2016). Migration, Ethnicity, and the Educational Gradient in the Jakarta Mega-Urban Region: A Spatial Analysis. Bulletin of Indonesian Economic Studies.

DOI: $10.1080 / 00074918.2015 .1129050$

Koengkan, M., Fuinhas, J. A., \& Santiago, R. (2020). The relationship between $\mathrm{CO} 2$ emissions, renewable and non-renewable energy consumption, economic growth, and urbanisation in the Southern Common Market. Journal of Environmental Economics and Policy, 119. doi:10.1080/21606544.2019.1702902

Kotler, P. \& Keller, K.L. (2008). Manajemen Pemasaran, Jilid 1. Jakarta: Erlangga

Larasati, Kirana. (2016). Pengaruh Politik Ekologi Terhadap Pembangunan 
Berkelanjutan di Indonesia (Skripsi). Medan: Universitas Sumatera Utara.

Nomleni, P., Hariadi, M., Purnama, I.K. (2013). Sentiment Analysis Based Big Data. Seminar Nasional ke - 9: Rekayasa Teknologi Industri dan Informasi. Surabaya: Institut Teknologi Sepuluh November

PT. MRT Jakarta. (2020). Laporan Tahunan (Annual Report) MRT Jakarta 2019. Jakarta: PT. MRT Jakarta

Rogers, P. P., Jalal, K. F., \& Boyd, J. A. (2012). An introduction to sustainable development. Routledge.

Sachs, J. D. (2015). The Age of Sustainable Development. Columbia University Press. ISBN 978-0-231-17314-8.

Sirait, Emyana Ruth Eritha. 2016. Implementation of Big data Technology In Government Institutions In Indonesia. Jurnal Penelitian Pos dan Informatika. DOI: $10.17933 /$ jppi.2016.060201

Soekanto, S. (1977). Kesadaran hukum dan kepatuhan hukum. Jurnal Hukum dan Pembangunan, 7(6), 462-470.

Sukmadinata, N.S. (2011). Metode Penelitian Pendidikan. Bandung: Remaja Rosadakarya.

Sumaedi, S., Bakti, M.Y., Astrini, N.J., Rakhmawati, T., Widianti, T., \& Yarmen, M. (2014). Public Transport Passengers Behavioural Intentions: Paratransit in Jabodetabek-Indonesia. ISBN 978-9814585-24-8. Springer Science dan Business Media.

Sutopo, A., Arthati, Fitriana, F., Rahmi, Anzalika, U .(2014). Kajian Indikator Lintas Sektor: Kajian Indikator Sustainable Development Goals (SDGs). Nomor Katalog :3102020. Nomor Publikasi : 07330.1413.Jakarta: Badan Pusat Statistik.
Tamin, O.Z. (2000). Perencanaan dan Pemodelan Transportasi. ISBN 979-9299-10-1. Bandung: Institut Teknologi Bandung.

Tao, H., Bhuiyan, M.Z.A., Rahman, M.A., Wang, G., Wang, T., Ahmed, M.M., \& Li, J. (2019). Economic Perspective Analysis of Protecting Big data Security and Privacy. Future Generation Computer Systems.doi:10.1016/j.future.2019.03.04 2

Tuan, V. A.(2015). Mode Choice Behavior and Modal Shift to Public Transport in Developing Countries: The Case of Hanoi City. Journal of the Eastern Asia Society for Transportation

Studies.https://doi.org/10.11175/easts.1 1.473

Wells G.R. (1975). Comprehensive Transport Planning. London: Charles Griffin dan Company Ltd.

Yudhistira, M.H., Indriyani, W., Pratama, A.P., Sofiandi, Y., \& Kurniawan, Y. R. (2018). Transportation network and changes in urban structure: Evidence from the Jakarta Metropolitan Area. Journal of Research in Transportation Economics.

DOI:

10.1016/j.retrec.2018.12.003

Siegrist, M., \& Cvetkovich, G. (2000).

Perception of hazards: The role of social trust and knowledge. Risk analysis, 20(5), 713-720.

Stoner, J.A.F. \& Freeman, R.E. (1989). Management. Fourth Edition. New Jersey: Prentice-Hall, Inc.

Winslott-Hiselius, L., Brundell-Freij, K., Vagland, Å., \& Byström, C. (2009). The development of public attitudes towards the Stockholm congestion trial. Transportation Research Part A: Policy and Practice, 43(3), 269282. doi:10.1016/j.tra.2008.09.006 
Yudho, W., \& Tjandrasari, H. (2017). Efektivitas Hukum Dalam Masyarakat. Jurnal Hukum $\mathcal{\sigma}^{\circ}$ Pembangunan, 17(1), 57. doi:10.21143/jhp.vol17.no1.1227

Zhu, X., \& Liu, S. (2004). Analysis of the impact of the MRT system on accessibility in Singapore using an integrated GIS tool. Journal of Transport Geography, 12(2), 89101. doi:10.1016/j.jtrangeo.2003.10.003 